\title{
Reviews and syntheses: Calculating the global contribution of coralline algae to total carbon burial
}

\author{
L. H. van der Heijden ${ }^{1,2}$ and N. A. Kamenos ${ }^{1}$ \\ ${ }^{1}$ School of Geographical and Earth Sciences, University of Glasgow, Glasgow, Scotland \\ ${ }^{2}$ Department of Earth Sciences, Faculty of Geosciences, Utrecht University, Utrecht, the Netherlands \\ Correspondence to: L. H. van der Heijden (luukvdheijden88@gmail.com)
}

Received: 7 April 2015 - Published in Biogeosciences Discuss.: 26 May 2015

Revised: 20 October 2015 - Accepted: 23 October 2015 - Published: 10 November 2015

\begin{abstract}
The ongoing increase in anthropogenic carbon dioxide $\left(\mathrm{CO}_{2}\right)$ emissions is changing the global marine environment and is causing warming and acidification of the oceans. Reduction of $\mathrm{CO}_{2}$ to a sustainable level is required to avoid further marine change. Many studies investigate the potential of marine carbon sinks (e.g. seagrass) to mitigate anthropogenic emissions, however, information on storage by coralline algae and the beds they create is scant. Calcifying photosynthetic organisms, including coralline algae, can act as a $\mathrm{CO}_{2}$ sink via photosynthesis and $\mathrm{CaCO}_{3}$ dissolution and act as a $\mathrm{CO}_{2}$ source during respiration and $\mathrm{CaCO}_{3}$ production on short-term timescales. Longterm carbon storage potential might come from the accumulation of coralline algae deposits over geological timescales. Here, the carbon storage potential of coralline algae is assessed using meta-analysis of their global organic and inorganic carbon production and the processes involved in this metabolism. Net organic and inorganic production were estimated at $330 \mathrm{~g} \mathrm{C} \mathrm{m}^{-2} \mathrm{yr}^{-1}$ and $900 \mathrm{~g} \mathrm{CaCO}_{3} \mathrm{~m}^{-2} \mathrm{yr}^{-1}$ respectively giving global organic/inorganic $\mathrm{C}$ production of $0.7 / 1.8 \times 10^{9} \mathrm{tC} \mathrm{yr}^{-1}$. Calcium carbonate production by free-living/crustose coralline algae (CCA) corresponded to a sediment accretion of $70 / 450 \mathrm{~mm} \mathrm{kyr}^{-1}$. Using this potential carbon storage for coralline algae, the global production of free-living algae/CCA was $0.4 / 1.2 \times 10^{9} \mathrm{tC}^{-1}$ suggesting a total potential carbon sink of $1.6 \times 10^{9}$ tonnes per year. Coralline algae therefore have production rates similar to mangroves, salt marshes and seagrasses representing an as yet unquantified but significant carbon store, however, further empirical investigations are needed to determine the dynamics and stability of that store.
\end{abstract}

\section{Carbon storage and coralline algae}

An increase in exploitation of fossil fuels since the mid-18th century caused a rise in the partial pressure of carbon dioxide in both atmospheric $\left(\mathrm{CO}_{2}\right)$ and oceanic $\left(p \mathrm{CO}_{2}\right)$ reservoirs (Sabine et al., 2004; Meehl et al., 2007). Atmospheric $\mathrm{CO}_{2}$ has risen from $280 \mathrm{ppm}$ in 1750 (Denman et al., 2007) to nearly $400 \mathrm{ppm}$ in 2014 (Diugokencky and Tans, 2015) at a rate unprecedented in geological history (Denman et al., 2007). The marine environment has been changing rapidly in the last few centuries too (Cubasch et al., 2013), with increasing $\mathrm{CO}_{2}$ causing warming and acidification of the Earth's oceans (Caldeira and Wickett, 2005).

Concentrations of atmospheric $\mathrm{CO}_{2}$ simulated by coupled climate-carbon cycle models range between 730 and 1200 ppm by 2100 (Meehl et al., 2007). Therefore, a reduction of atmospheric $\mathrm{CO}_{2}$ to a sustainable level is needed to avoid further environmental damage (Collins et al., 2013; Kirtman et al., 2013).

The oceans are a major sink of anthropogenic $\mathrm{CO}_{2}$ emissions, accounting for $\sim 48 \%$ of emissions absorption since the Industrial Revolution (Sabine et al., 2004). Significantly, around $50 \%$ of the global primary production (which uses $p \mathrm{CO}_{2}$ ) is by marine organisms (Beardall and Raven, 2004) with marine microalgae and bacteria being the dominant source of primary production and respiration (Duarte and Cebrian, 1996; del Giorgio and Duarte, 2002; Duarte et al., 2005). Vegetated marine habitats, including macroalgae and seagrasses, are often neglected from accounts of the global ocean carbon cycle because of their limited extent (cover $<2 \%$ of ocean surface; Duarte and Cebrian, 1996). However, vegetated coastal habitats have a great carbon storage 
capacity (Duarte et al., 2005) and the potential of marine coastal vegetation as a sink for anthropogenic carbon emissions (blue carbon) is becoming of interest (Nellemann et al., 2009). These marine macrophyte ecosystems have slow turnover rates and are therefore more effective carbon sinks than planktonic ecosystems (Smith, 1981).

Red coralline algae are present from the tropics to polar regions (Johansen, 1981; Steneck, 1986; Foster, 2001; Wilson, 2004). Coralline algae are important for ecosystems due to their role in carbon cycling, creating and maintaining habitats, and reef building/structuring roles (Nelson, 2009). They are divided in two morpho-functional groups; geniculated (articulated) and non-geniculated (non-articulated; Johansen, 1981). The morphological states range from totally adherent to having non-adherent margins (leafy) to totally non-adherent (free-living, e.g. rhodoliths, maerls and nodules; Steneck, 1986; Cabioch, 1988). The calcium carbonate skeleton of coralline algae prevents them from breaking down quickly compared to fleshy algae (Borowitzka, 1982; Wilson, 2004). Coralline algal species have been observed in the fossil record since the early Cretaceous (Aguirre et al., 2000) and coralline algal communities reach $500-800$ years (Adey and Macintyre, 1973; Kamenos, 2010) with $~ 8000$ year-old free-living coralline algal beds present in France (Birkett et al., 1998).

Coralline algae are important contributors to the marine calcium carbonate $\left(\mathrm{CaCO}_{3}\right)$ deposited in the coral reef sediments (Goreau, 1963; Adey and Macintyre, 1973) and account for approximately $25 \%$ of $\mathrm{CaCO}_{3}$ accumulation within coastal regions (Martin et al., 2007). Calcifying photosynthesisers are both a sink and a source of $\mathrm{CO}_{2}$ (Frankignoulle, 1994). Coralline algae act as a $\mathrm{CO}_{2}$ sink in the processes of photosynthesis and $\mathrm{CaCO}_{3}$ dissolution and act as a $\mathrm{CO}_{2}$ source in the processes of respiration and $\mathrm{CaCO}_{3}$ production (Martin et al., 2005, 2006, 2007, 2013a; Barron et al., 2006; Kamenos et al., 2013). We aim to estimate the global distribution of coralline algae, and from that, determine their potential role in long-term total carbon burial.

\section{Coralline algal succession and small-scale distribution}

The distribution and abundance of coralline algae is determined by ecological processes including growth, succession and competition (Steneck, 1986; McCoy and Kamenos, 2015) as well as by environmental conditions such as disturbance, temperature and irradiance (Adey and Macintyre, 1973; Kamenos et al., 2004; Gattuso et al., 2006). Coralline algae grow both laterally to increase area and vertically to increase thickness (Steneck, 1986). Coralline algal vertical accretion rates vary widely from 0.1 to $80 \mathrm{~mm} \mathrm{yr}^{-1}$ (Adey and McKibbin, 1970; Steneck and Adey, 1976; Edyvean and Ford, 1987). Succession in coralline algae occurs when thick and/or branched crusts replace thinner unbranched crusts
(Adey and Vassar, 1975; Steneck, 1986). Succession seems most rapid in the tropics, where colonization and succession takes $\sim 1$ year, compared to 6-7 years in the boreal North Pacific and $>10$ years in the subarctic North Atlantic (Steneck, 1986; McCoy and Ragazzola, 2014). In shallow productive zones coralline algae require disturbances, mainly herbivory as well as water motion, to remain clear of fleshy algae and invertebrates (Steneck, 1986). However, towed fishing gear (e.g. trawling) can easily damage rhodoliths (maerl; Hall-Spencer and Moore, 2000; Kamenos and Moore, 2003). Overall, coralline algal distribution is likely primarily determined by irradiance and temperature (Adey and McKibbin, 1970; Adey and Adey, 1973; Gattuso et al., 2006).

\subsection{Global distribution}

Coralline algae are ecosystem engineers (Nelson, 2009), major framework builders and carbonate producers, especially in temperate and cold water benthic ecosystems (Nelson, 1988; Freiwald and Henrich, 1994; Foster, 2001; Gherardi, 2004; Bracchi and Basso, 2012; Savini et al., 2012; Basso, 2012). Coralline algae are found from the low intertidal to the infralittoral and circalittoral zones (> $200 \mathrm{~m}$ depth; Steneck, 1986; Basso, 1998; Foster, 2001) and have a worldwide spatial distribution (Fig. 1; Table S2 in the Supplement). While crustose coralline algae (CCA) grow exclusively on hard surfaces, free-living coralline algae are able to form rhodoliths when they settle on non-cohesive particulate substrates or are detached from existing hard substrates by fragmentation (Bosence, 1983).

\subsection{Surface covered by coralline algae}

The surface of the coastal zone covered by coralline algae varies spatiotemporally and differs for free-living algae, geniculate and CCA (Table S1). The average coralline algal sea bed coverage from published studies is $52.5 \%$ for CCA, $45.0 \%$ for rhodoliths and $45.0 \%$ for coralline algae overall. Figueiredo et al. (2008) indicate that the surface covered by CCA on the Abrolhos Bank $\left(20900 \mathrm{~km}^{2}\right)$ in Brazil ranges from $5-40 \%$ on the reef flats, $30-80 \%$ on the reef crests and $10-50 \%$ on the reef walls with coverage varying due to differences in the abundance of turf algae and herbivory pressure. On coral reefs, CCA (e.g. Porolithon onkodes) can cover $\sim 40 \%$ of the reef slope (Littler and Doty, 1975; Stearn et al., 1977), $60 \%$ of the reef flat and $5 \%$ of lagoon sites (Atkinson and Grigg, 1984) with rhodoliths covering up $90 \%$ of the reef crest (Sheveiko, 1981) and $90 \%$ of the seaward shallow reef slope (Chisholm, 1988). Importantly, the area covered by coralline algae is not necessarily lower in regions dominated by other algal forms, because of their ability to occur on the primary substratum (up to $90 \%$ ) or as epiphytes on larger algae (Johansen, 1981). 


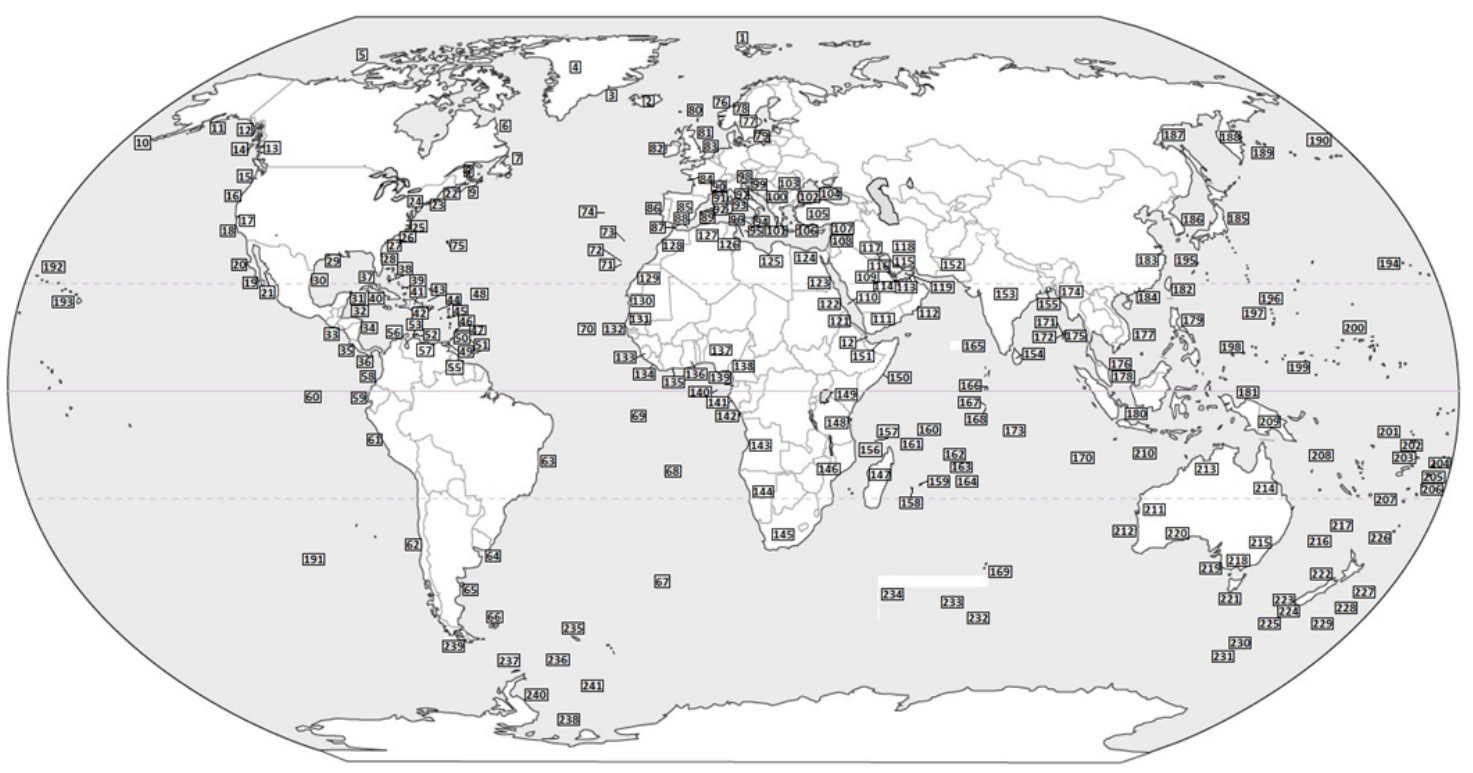

Figure 1. The global distribution of the three coralline algae Families (Corallinaceae, Hapalidiaceae and Sporolithaceae; for species list per country/region see Table S2). The numbers indicate: 1. Spitsbergen, 2. Iceland, 3. Greenland, east, 4. Greenland, 5. Canada, Arctic, 6. Canada, Labrador, 7. Canada, Newfoundland, 8. Canada, New Brunswick, 9. Canada, Nova Scotia, 10. USA, Aleutian Islands, Alaska, 11. USA, Alaska, 12. Revillagigedo Islands, USA, 13. Canada, British Columbia, 14. Canada, Queen Charlotte Islands, 15. USA, Washington, 16. USA, Oregon, 17. USA, California, 18. USA, Channel Islands, California, 19. Mexico, Baja California, 20. Mexico, Isla Guadalupe, 21. USA, Gulf of California, 22. USA, Maine, 23. USA, New Hampshire, 24. USA, Connecticut, 25. USA, Virginia, 26. USA, North Carolina, 27. USA, South Carolina, 28. USA, Florida, 29. USA, Texas, 30. Mexico, 31. Belize, 32. Honduras, 33. El Salvador, 34. Nicaragua, 35. Costa Rica, 36. Panama, 37. Cuba, 38. Bahamas, 39. Caicos Islands, 40. Jamaica, 41. Hispaniola, Dominican Republic, 42. Puerto Rico, 43. Virgin Islands, USA, 44. Saints Kitts, 45. Martinique, 46. Barbados, 47. Saint Thomas, Barbados, 48. Lesser Antilles, 49. Trinidad, 50. Tobago, 51. Trinidad and Tobago, 52. Curacao, 53. Netherlands Antilles, 54. Tropical and Subtropical Western Atlantic, 55. Guyana, 56. Aves, island of Venezuela, 57. Venezuela, 58. Colombia, 59. Ecuador, 60. Galapagos Islands, 61. Peru, 62. Chile, 63. Brazil, 64. Uruguay, 65. Argentina, 66. Falkland Islands, 67. Gough Island, 68. Saint Helena, 69. Ascension, 70. Cape Verde Islands, 71. Canary Islands, 72. Portugal, Salvage Islands, 73. Madeira, 74. Azores, 75. Bermuda, 76. Norway, 77. Sweden, 78. Scandinavia, 79. Baltic Sea, 80. Faroe Islands, 81. Great-Britain, 82. Ireland, 83. Netherlands, 84. France, 85. Spain, 86. Portugal, 87. Gibraltar, 88. Spain, Isla de Alboran, 89. Balearic Islands, Spain, 90. Monaco, 91. Corsica, 92. Sardinia, 93. Italy, 94. Sicily, 95. Malta, 96. Italy, Pelagie Islands, 97. Italy, Adriatic Sea, 98. Slovenia, 99. Croatia, 100. Albania, 101. Greece, 102. Bulgaria, 103. Romania, 104. Black Sea, 105. Turkey, 106. Cyprus, 107. Syria, 108. Israel, 109. Saudi Arabia, 110. Red Sea, 111. Yemen, 112. Oman, 113. Dubai, 114. Abu Dhabi, 115. Qatar, 116. Bahrain, 117. Kuwait, 118. Iran, 119. Persian Gulf, 120. Djibouti, 121. Eritrea, 122. Sudan, 123. Egypt, Red Sea, 124. Egypt, 125. Libya, 126. Tunisia, 127. Algeria, 128. Morocco, 129. Western Sahara, 130. Mauritania, 131. Senegal, 132. Gambia, 133. Sierra Leone, 134. Liberia, 135. Cote d'Ivoire, 136. Ghana, 137. Nigeria, 138. Cameroon, 139. Equatorial Guinea, 140. São Tomé and Principe, 141. Gabon, 142. Congo, 143. Angola, 144. Namibia, 145. South Africa, 146. Mozambique, 147. Madagascar, 148. Tanzania, 149. Kenya, 150. Somalia, 151. Ethiopia, 152. Pakistan, 153. India, 154. Sri Lanka, 155. Bangladesh, 156. Comores and Mayotte, 157. Aldabra Islands, 158. Réunion, 159. Mauritius, 160. Seychelles, 161. Amirante Islands, 162. Saya de Malha Bank, 163. Cargados Carajos, 164. Rodrigues Island, 165. India, Laccadive Islands, 166. Maldives, 167. Chagos Archipelago, 168. Diego Garcia Atoll, 169. Amsterdam Island, 170. Cocos (Keeling) Islands, 171. Andaman Islands, India, 172. Nicobar Islands, India, 173. Indian Ocean Islands, 174. Myanmar, 175. Thailand, 176. Malaysia, 177. Vietnam, 178. Singapore, 179. Philippines, 180. Indonesia, 181. Indonesia, New Guinea, 182. Taiwan, 183. China, 184. Hong Kong, 185. Japan, 186. Korea, 187. Russia, east, 188. Russia, Kamchatka, 189. Russia, Commander Islands, 190. Saint Paul Island, 191. Easter Island, 192. Northwestern Hawaiian Islands, USA, 193. Hawaiian Islands, USA, 194. Wake Atoll, 195. Ryukyu Islands, Japan, 196. Mariana Islands, 197. Guam, 198. Republic of Palau, 199. Federated States of Micronesia, 200. Marshall Islands, 201. Tuvalu, 202. Samoan Archipelago, 203. American Samoa, 204. Central Polynesia, 205. French Polynesia, 206. Tahiti, 207. Fiji, 208. Solomon Islands, 209. Papua New Guinea, 210. Christmas Island, Australia, 211. Australia, western , 212. Australia, Houtman Abrolhos, 213. Australia, Northern Territory, 214. Australia, Queensland, 215. Australia, New South Wales, 216. Australia, Lord Howe Island, 217. Australia, Norfolk Island, 218. Australia, Victoria, 219. Australia, Bass Strait, 220. Australia, South, 221. Tasmania, 222. New Zealand, 223. New Zealand, Stewart Islands/Rakiura, 224. New Zealand, Snares Islands/Tini Heke, 225. New Zealand, Auckland Islands, 226. New Zealand, Kermadec Islands, 227. New Zealand, Chatman Islands, 228. New Zealand, Bounty Island, 229. New Zealand, Antipodes Islands, 230. Antarctica, Campbell Islands, 231. Antarctica, Macquarie Island, 232. Antarctica, Heard Island, 233. Antarctica, Kerguelen, 234. Antarctica, Crozet Islands, 235. Antarctica, South Georgia, 236. Antarctica, South Orkney Islands, 237. Antarctica, South Shetland Islands, 238. Antarctica, Fuegia, 239. Antarctica, Tierra del Fuego, 240. Antarctica, Peninsula, and 241. Antarctica, Subantarctic Islands. 
Table 1. Net primary production (daily and annual) of coralline algae (communities) from different depths and locations. Yearly primary production indicated in italics are an estimate of the yearly production by taking a daily production and modifying this to a yearly production $(\times 365)$. The median production for crustose coralline algae and free-living algae is indicated.

\begin{tabular}{|c|c|c|c|c|c|}
\hline Structure or species & Location & Depth & $\begin{array}{l}\text { Primary production } \\
\qquad\left(\mathrm{g} \mathrm{C} \mathrm{m}^{-2} \mathrm{~d}^{-1}\right)\end{array}$ & $\begin{array}{l}\text { Primary production } \\
\qquad\left(\mathrm{gC} \mathrm{m}^{-2} \mathrm{yr}^{-1}\right)\end{array}$ & Reference \\
\hline Crustose coralline algae & & & & 370 & This study $(n=35)$ \\
\hline Crustose coralline algae & San Salvador Island, Bahamas & $81 \mathrm{~m}$ & 0.07 & 26 & Littler et al. (1986) \\
\hline Hydrolithon spp. & Klein Piscadera, Curacao & $25 \mathrm{~m}$ & 0.21 & 77 & Vooren $(1981)$ \\
\hline Sporolithon ptychoides & Klein Piscadera, Curacao & $25 \mathrm{~m}$ & 0.21 & 78 & Vooren (1981) \\
\hline Pseudolithoderma nigrum & Wilson Cove, California, USA & & 0.40 & 146 & Littler and Murray (1974) \\
\hline Sporolithon erythraeum & Waikiki reef, Hawaii, USA & & 0.50 & 183 & Littler (1973) \\
\hline Porolithon onkodes & Waikiki reef, Hawaii, USA & & 0.50 & 183 & Littler (1973) \\
\hline Porolithon gardineri & Waikiki reef, Hawaii, USA & & 0.50 & 183 & Littler (1973) \\
\hline Hydrolithon decipiens & Wilson Cove, California, USA & & 0.50 & 183 & Littler and Murray (1974) \\
\hline Phymatolithon foecundum $+P$. Tenue & Young Sound, NE Greenland & $17-36 \mathrm{~m}$ & & $70-300$ & Roberts et al. (2002) \\
\hline Reef building coralline algae & Eniwetok Atoll, Hawaii, USA & $2 \mathrm{~m}$ & 0.66 & 240 & Marsh (1970) \\
\hline Porolithon conicum & Lizard Island, Australia & $0-18 \mathrm{~m}$ & $0.18-1.16$ & $66-423$ & Chisholm (1988) \\
\hline Lithophyllum sp. & Coral reef, Curacao & $0.5-3 \mathrm{~m}$ & 0.70 & 256 & Wanders (1976) \\
\hline Neogoniolithon fosliei & Lizard Island, Australia & $0-6 \mathrm{~m}$ & $0.46-0.95$ & $168-347$ & Chisholm (1988) \\
\hline Porolithon onkodes & Lizard Island, Australia & $0-6 \mathrm{~m}$ & $0.37-1.35$ & $135-493$ & Chisholm (1988) \\
\hline Hydrolithon reinboldii & Lizard Island, Australia & $3-6 \mathrm{~m}$ & $0.86-0.90$ & $314-329$ & Chisholm (1988) \\
\hline Lithophyllum intermedium & Coral reef, Curacao & $0.5-3 \mathrm{~m}$ & 0.90 & 329 & Wanders (1976) \\
\hline Lithophyllum congestum & Coral reef, Curacao & $0.5-3 \mathrm{~m}$ & 1.00 & 365 & Wanders (1976) \\
\hline Crustose coralline algae & Coral reef, Curacao & $0.5-3 \mathrm{~m}$ & 1.00 & 370 & Wanders (1976) \\
\hline Porolithon pachydermum & Coral reef, Curacao & $0.5-3 \mathrm{~m}$ & 1.10 & 402 & Wanders (1976) \\
\hline Lithophyllum sp. & Coral reef, Curacao & $0.5-3 \mathrm{~m}$ & 1.10 & 402 & Wanders (1976) \\
\hline Neogoniolithon solubile & Coral reef, Curacao & $0.5-3 \mathrm{~m}$ & 1.40 & 511 & Wanders (1976) \\
\hline Melobesioid species & Waikiki reef, Hawaii, USA & & 1.50 & 548 & Littler (1973) \\
\hline Mainly Neogoniolithon frutescens & Coral reef, Mooria, Tahiti & $0.75 \mathrm{~m}$ & 2.00 & 730 & Sournia (1976) \\
\hline Porolithon onkodes & Hawaiian Reef, USA & $5 \mathrm{~m}$ & 2.20 & 803 & Littler and Doty (1975) \\
\hline Porolithon gardineri & Hawaiian Reef, USA & $5 \mathrm{~m}$ & 2.40 & 876 & Littler and Doty (1975) \\
\hline Corallina elongata & Marseille, France & $5 \mathrm{~m}$ & 2.50 & 912 & El Haïkali et al. (2004) \\
\hline Hydrolithon reinboldii & Waikiki reef, Hawaii, USA & & 2.60 & 949 & Littler (1973) \\
\hline Neogoniolithon conicum Lab. & Lizard Island, Australia & $0-18 \mathrm{~m}$ & $0.6-4.65$ & $219-1697$ & Chisholm (2003) \\
\hline Hydrolithon reinboldii Lab. & Lizard Island, Australia & $0-6 \mathrm{~m}$ & $1.6-3.8$ & $584-1387$ & Chisholm (2003) \\
\hline Neogoniolithon brassica-florida Lab. & Lizard Island, Australia & $0-6 \mathrm{~m}$ & $2.45-3.35$ & $894-1223$ & Chisholm (2003) \\
\hline Neogoniolithon conicum In situ & Lizard Island, Australia & $0-18 \mathrm{~m}$ & $0.85-5.9$ & $310-2154$ & Chisholm (2003) \\
\hline Neogoniolithon brassica-florida In situ & Lizard Island, Australia & $0-6 \mathrm{~m}$ & $2.15-4.7$ & $785-1716$ & Chisholm (2003) \\
\hline Hydrolithon onkodes In situ & Lizard Island, Australia & $0-3 \mathrm{~m}$ & $1.75-6.55$ & $639-2391$ & Chisholm (2003) \\
\hline Hydrolithon reinboldii In situ & Lizard Island, Australia & $3-6 \mathrm{~m}$ & $4.15-4.35$ & $1515-1588$ & Chisholm (2003) \\
\hline Hydrolithon onkodes Lab. & Lizard Island, Australia & $0-3 \mathrm{~m}$ & $4.01-6.05$ & $1464-2208$ & Chisholm (2003) \\
\hline Free-living algae & & & & 173 & This study $(n=4)$ \\
\hline Nongeniculate corallines & San Salvador Island, Bahamas & $76 \mathrm{~m}$ & 0.15 & 55 & Littler et al. (1991) \\
\hline Maerl beds & Bay of Brest, France & $0.3-7.9 \mathrm{~m}$ & 0.38 & 138 & Martin et al. (2005) \\
\hline Lithophyllum sp. & San Salvador Island, Bahamas & $76 \mathrm{~m}$ & 0.57 & 208 & Littler et al. (1991) \\
\hline Lithothamnion corallioides & Bay of Brest, France & $1-10 \mathrm{~m}$ & & $10-600$ & Martin et al. (2006) \\
\hline
\end{tabular}

\section{Processes and metabolism}

While coralline algae are slow growing, their high abundance and spatial distribution indicate their production is likely important (Johansen, 1981) and they are major contributors to the carbon and carbonate cycles of coastal environments (Martin et al., 2013a). Organic production relates to the photosynthetic capacity of coralline algae, while inorganic production relates to the calcium carbonate production (Johansen, 1981).

\subsection{Organic production}

Organic production of coralline algae is low compared to other marine plants (Johansen, 1981; Steneck, 1986). How- ever, because of their high abundance and worldwide dispersal, corallines can contribute significantly to the total marine primary production (Roberts et al., 2002). Production of one mole of organic material (photosynthesis) decreases dissolved inorganic carbon (DIC) by one mole:

$\mathrm{CO}_{2}+\mathrm{H}_{2} \mathrm{O} \rightarrow \mathrm{CH}_{2} \mathrm{O}+\mathrm{O}_{2}$.

Primary production also decreases $p \mathrm{CO}_{2}$, however the magnitude of these changes depends on the equilibrium constants (Johansen, 1981). Respiration increases both DIC and $p \mathrm{CO}_{2}$ (Johansen, 1981). Coralline algal respiration is between $20-60 \%$ of gross primary production (Marsh, 1970; Littler, 1973; Littler and Murray, 1974; Sournia, 1976; Wanders, 1976). Net community production for coralline algae 
Table 2. The global average production rates of autotrophic coastal communities. Macroalgae in Gattuso et al. (1998) were macrophytedominated. Macrophytobenthic communities in Charpy-Roubaud and Sournia (1990) included brown algae, seagrasses, mangroves and salt marshes.

\begin{tabular}{|c|c|c|c|}
\hline \multirow[t]{2}{*}{ Community } & \multicolumn{2}{|c|}{ Production rate } & \multirow[t]{2}{*}{ References } \\
\hline & $\left(\mathrm{gC} \mathrm{m}^{-2} \mathrm{~d}^{-1}\right)$ & $\left(\mathrm{gC} \mathrm{m}^{-2} \mathrm{yr}^{-1}\right)$ & \\
\hline Coralline algae (average) & 0.9 & 329 & This study $(n=39)$ \\
\hline Free-living algae & $0.15-0.83$ & 173 & This study $(n=4)$ \\
\hline \multirow[t]{2}{*}{ Crustose coralline algae } & $0.07-5$ & 370 & This study $(n=35)$ \\
\hline & $0.9-5$ & & Chisholm (2003) \\
\hline Benthic fleshy algae & $0.1-4$ & & Larkum (1983) \\
\hline Turf algae & $1-6$ & & Larkum (1983) \\
\hline \multirow[t]{2}{*}{ Mangroves } & & 221 & Duarte et al. (2005) \\
\hline & & 1081 & Gattuso et al. (1998) \\
\hline \multirow[t]{2}{*}{ Salt marshes } & & 1585 & Duarte et al. (2005) \\
\hline & & 210 & Gattuso et al. (1998) \\
\hline \multirow[t]{2}{*}{ Seagrasses } & $1-7^{\mathrm{L}}$ & $1211^{\mathrm{D}}$ & $\mathrm{L}=\operatorname{Larkum}(1983)^{\mathrm{D}}=$ Duarte et al. (2005) \\
\hline & & 502 & $\begin{array}{l}\text { Ranwell (1966); Kirby and Gosselink (1976); Odum (1974); Turner (1976); } \\
\text { Thayer and Adams (1975); Nienhuis and Bree (1977); Zieman (1975) }\end{array}$ \\
\hline \multirow[t]{2}{*}{ Macroalgae } & & 1587 & Duarte et al. (2005) \\
\hline & & 222 & Gattuso et al. (1998) \\
\hline Benthic diatoms & & 123 & Cadee and Hegeman (1974) \\
\hline \multirow[t]{2}{*}{ Coastal phytoplankton } & $0.1-0.5^{\mathrm{L}}$ & $196^{\mathrm{W}}$ & $\mathrm{L}=$ Larkum $(1983)^{\mathrm{W}}=$ Woodwell et al. (1973) \\
\hline & & & Cadee and Hegeman, (1974); Gieskes and Kraay (1975) \\
\hline \multirow[t]{2}{*}{ Coral reefs } & & 148 & Duarte et al. (2005) \\
\hline & & 120 & Gattuso et al. (1998) \\
\hline Macrophytobenthos & & 375 & Charpy-Roubaud and Sournia (1990) \\
\hline
\end{tabular}

is induced or limited by environmental parameters including light reaching the communities (Gattuso et al., 2006; Martin et al., 2006; Burdett et al., 2014), temperature (Martin et al., 2006; Kamenos and Law, 2010) and nutrient availability (Smith et al., 2001). For example, Chisholm (2003) suggested that the high rates of productivity measured in situ at Lizard Island, Australia, came from the coralline algae that derive nutrients from the underlying reef.

\subsection{Inorganic production and accumulation}

Photosynthesis also plays a crucial role in the production of inorganic material as it creates the environment in which calcification occurs (Johansen, 1981). The ratio of inorganicorganic production is high in coralline algae, compared to non-coralline seaweeds (Johansen, 1981). Precipitation of one mole $\mathrm{CaCO}_{3}$ decreases DIC by one mole and total alkalinity by two moles:

$\mathrm{Ca}^{2+}+2 \mathrm{HCO}_{3}^{-} \rightarrow \mathrm{CaCO}_{3}+\mathrm{H}_{2} \mathrm{O}+\mathrm{CO}_{2}$.

For calcium carbonate to be deposited an alkaline environment is required, as well as high concentrations of calcium and carbonate (Johansen, 1981). Calcification of coralline algae occurs internally, compared to external calcification in corals and other invertebrates (Chisholm, 2003). The cellwalls of coralline algae are composed of calcium carbonate, and mainly consist of high Mg-calcite (HMC: $>4 \%$ wt of $\mathrm{MgCO}_{3}$; Moberly, 1968; Kamenos et al., 2008; Basso, 2012).
Coralligenous algal-dominated rocky bottoms and rhodolith beds are among the highest algal carbonate producers when compared with Posidonia oceanica meadows, sandy bottom communities, Caulerpa-Cymodocea meadows, coralligenous animal-dominated, photophilic algae and hemisciaphili algal communities (Canals and Ballesteros, 1997). The quantity of calcite production by coralline algae depends on their morphology (e.g., geniculate or non-geniculate, thick or thin crusts), growth rate and the environmental conditions (Basso, 2012). Coralline algal calcification is indirectly affected by temperature, often over a season cycle, as well as by light limitation (Martin et al., 2006).

\section{Potential global contribution of coralline algae to total carbon burial}

The shallow-water ocean environment (i.e. bays, estuaries, lagoons, banks, and continental shelves) accounts for 14$30 \%$ of the oceanic primary production, $80 \%$ of organic material burial and $\sim 50 \%$ of $\mathrm{CaCO}_{3}$ deposition (Gattuso et al., 1998). The total surface area of the coastal zone, the potential habitat for benthic coralline algae, is estimated between $0.45-49.4 \times 10^{12} \mathrm{~m}^{2}$ (Charpy-Robaud and Sournia, 1990). The coastal area, that has depths ranging between 0 and $200 \mathrm{~m}$ covers $7.49 \%$ of the world ocean, which corresponds to $27.123 \times 10^{12} \mathrm{~m}^{2}$ (Menard and Smith, 1966). 
Table 3. The total global production of different coastal communities compared to the total marine oceanic production. The macrophytobenthic community in Charpy-Roubaud and Sournia (1990) included brown algae, seagrasses, mangroves and salt marshes.

\begin{tabular}{lrl}
\hline Community & $\begin{array}{r}\text { Total global production } \\
\text { (in } 10^{9} \mathrm{tC}^{-1} \text { ) }\end{array}$ & \\
\hline Coralline algae & 0.7 & This study (n=39) \\
Microphytobenthic community & 0.34 & Charpy-Roubaud and Sournia (1990) \\
Algal beds and reefs community & 1.2 & Whittaker and Likens (1973) \\
Macrophytobenthic community & 2.55 & Charpy-Roubaud and Sournia (1990) \\
Phytoplankton community & $\geq 30$ & Charpy-Roubaud and Sournia (1990) \\
\hline Marine community & 48.5 & Field et al. (1998) \\
\hline
\end{tabular}

Charpy-Roubaud and Sournia (1990) suggest an area of $6.8 \times 10^{12} \mathrm{~m}^{2}$, because the average benthic photic zone of the world is shallower than $200 \mathrm{~m}$. Here we will use $33 \%$ of the coastal zone, which is the part that receives enough light for photosynthesis (Gattuso et al., 2006) and thus assuming that production mainly occurs in the top $66 \mathrm{~m}$ of the coastal zone. Because coralline algae usually attach to harder substrata (Bosence, 1983) the surface covered by coralline algae (Table S1) has to be taken into account. However, as there are substrates (e.g. sandy substrata or other soft-bottom substrates) that are an unsuitable habitat for coralline algae, to be conservative, we have assumed only half of the estimated surface coverage percentages estimated above contain coralline algae $(\mathrm{CCA}=26.25 \%$, rhodoliths $=22.5 \%$, coralline algae median $=22.5 \%$ ). At present we have an incomplete knowledge of the real distribution of coralline algae, so we estimate a global production based on the following parameters: the production of coralline algae (median), the top $66 \mathrm{~m}$ global coastal zone and the surface of this coastal zone covered by coralline algae $(22.5 \%)$. We use the median in/organic C production for coralline algae due to skewed data distribution (Zar, 1999) across available studies.

\subsection{Global coralline algal organic $C$ production}

Net primary production by coralline algae ranges widely from $10 \mathrm{~g} \mathrm{C} \mathrm{m}^{-2} \mathrm{yr}^{-1}$ by Lithothamnion corallioides in the Bay of Brest, France (Martin et al., 2006) to $2391 \mathrm{~g} \mathrm{C} \mathrm{m}^{-2} \mathrm{yr}^{-1}$ by Hydrolithon onkodes at Lizard Island, Australia (Chisholm, 2003), giving a median production of $329 \mathrm{~g} \mathrm{C} \mathrm{m}^{-2} \mathrm{yr}^{-1}(n=39$; Table 1) across depths and locations. Global $\mathrm{C}$ production may thus be as high as $0.7 \times 10^{9} \mathrm{tC} \mathrm{yr}^{-1}$. The daily production of coralline algae corresponds with the range of production of benthic fleshy algae, turf algae, sand algae, phytoplankton, seagrasses and zooxanthellae (Table 2) and estimated yearly coralline algal production rate $\left(329 \mathrm{~g} \mathrm{C} \mathrm{m}^{-2} \mathrm{yr}^{-1}\right)$ is in the range of production by mangroves, salt marshes and seagrasses and appears more productive than coastal phytoplankton, benthic diatoms and coral reefs (Table 2). Payri (2000) observed that the annual production of a coralline algal communities corre- sponds to approximately one third of the production of seagrass beds, which was also observed on the west-coast of France with a production ratio of 3.12 (Martin et al., 2005). A production ratio of 1.5-3.7 is observed in this study when compared to seagrass production rate studies (Table 2).

The estimated production of free-living coralline algae $\left(0.35 \times 10^{9} \mathrm{tC} \mathrm{yr}^{-1}\right)$ is in the range determined by other studies while the production for CCA $\left(0.88 \times 10^{9} \mathrm{tC} \mathrm{yr}^{-1}\right)$ is slightly higher (Table 3 ). Thus, with a global oceanic production estimated at $48.5 \times 10^{9} \mathrm{tC} \mathrm{yr}^{-1}$ (Field et al., 1998) coralline algal production represent a measurable component.

\subsection{Global inorganic coralline algal $C$ production and accumulation}

Studies focusing on coralline algae and calcium carbonate indicate a production range of $8-7400 \mathrm{~g} \mathrm{CaCO}_{3} \mathrm{~m}^{-2} \mathrm{yr}^{-1}$ and a median of $900 \mathrm{~g} \mathrm{CaCO}_{3} \mathrm{~m}^{-2} \mathrm{yr}^{-1}$ (Table 4). The global net calcium carbonate production using the previously estimated surface coverage was $1.8 \times 10^{9} \mathrm{tCaCO}_{3} \mathrm{yr}^{-1}$ for coralline algae. Thus $\mathrm{CaCO}_{3}$ production by coralline algae of $900 \mathrm{~g} \mathrm{CaCO}_{3} \mathrm{~m}^{-2} \mathrm{yr}^{-1}$ lies within the range of coral reef calcite production of $75-4000 \mathrm{~g} \mathrm{CaCO}_{3} \mathrm{~m}^{-2} \mathrm{yr}^{-1}$ (Canals and Ballesteros, 1997) and is comparable with the coral reef production rate in the Late Holocene $\left(1500 \mathrm{~g} \mathrm{CaCO}_{3} \mathrm{~m}^{-2} \mathrm{yr}^{-1}\right.$; Milliman, 1993). Basso (2012) estimated an average production rate of $5 \mathrm{~g} \mathrm{CaCO}_{3} \mathrm{~m}^{-2} \mathrm{yr}^{-1}$ for the coralline algae in the Mediterranean sea, however this included coralline algae occurring below $100 \mathrm{~m}$. Gattuso et al. (1998) suggested that communities in the coastal zone are responsible for more than $40 \%\left(23 \times 10^{9} \mathrm{tCaCO}_{3} \mathrm{yr}^{-1}\right)$ of the total marine calcium carbonate production. Thus the estimated calcite production by coralline algae is similar to the production of other coastal communities (e.g. coral reefs, banks and non/carbonate shelves) and might represent a large fraction of the coastal and total ocean calcite production (Gattuso et al., 1998).

Using average production rates for free-living algae and CCA a net inorganic production was estimated for these two groups. The net inorganic production for free- 
Table 4. Median net calcium carbonate production by coralline algae. Bracchi and Basso (2012) includes Lithophylloids, Canals and Ballesteros (1997) includes Peysonellia.

\begin{tabular}{|c|c|c|c|c|}
\hline Species & Location & Depth & $\begin{array}{r}\mathrm{CaCO}_{3} \text { production } \\
\left(\mathrm{g} \mathrm{CaCO}_{3} \mathrm{~m}^{-2} \mathrm{yr}^{-1}\right)\end{array}$ & Reference \\
\hline Crustose coralline algae & & & 1225 & This study ( $n=24)$ \\
\hline Epiphyte corallines on seagrass & Mallorca-Menorca shelf, Mediterranean. & $0-35 \mathrm{~m}$ & 68 & Canals and Ballesteros (1997) \\
\hline Mesophyllum & Barbados & fringing reef & 167 & Stearn et al. (1977) \\
\hline Coralligenous build-ups + coralline species & Mallorca-Menorca shelf, Mediterranean. & $70-90 \mathrm{~m}$ & 170 & Canals and Ballesteros (1997) \\
\hline Crustose coralline algae & Uva Island, Panama & reef flat & 190 & Eakin (1996) \\
\hline Neogoniolithon brassica-florida + geniculate & Mallorca-Menorca shelf, Mediterranean. & $0-10 \mathrm{~m}$ & 289 & Canals and Ballesteros (1997) \\
\hline Lithophyllum cabiochae & NW Mediterranean & $25 \mathrm{~m}$ & 292 & Martin and Gattuso (2009) \\
\hline Lithophyllum incrustans & South West Wales, United Kingdom & intertidal pools & 379 & Edyvean and Ford (1987) \\
\hline Epiphyte corallines on seagrass & Shark Bay, western Australia & $10 \mathrm{~m}$ & 500 & Walker and Woelkerling (1988) \\
\hline Neogoniolithon conicum & Lizard Island, Australia & $0-18 \mathrm{~m}$ & $300-1550$ & Chisholm (2000) \\
\hline Hydrolithon reinboldii & Lizard Island, Australia & $3-6 \mathrm{~m}$ & $910-1240$ & Chisholm (2000) \\
\hline Porolithon conicum & Lizard Island, Australia & $0-18 \mathrm{~m}$ & $318-1862$ & Chisholm (1988) \\
\hline Neogoniolithon & Barbados & fringing reef & 1225 & Stearn et al. (1977) \\
\hline Hydrolithon reinboldii & Lizard Island, Australia & $3-6 \mathrm{~m}$ & $1035-1512$ & Chisholm (1988) \\
\hline Lithophyllum & Barbados & fringing reef & 1355 & Stearn et al. (1977) \\
\hline Neogoniolithon brassica-florida & Lizard Island, Australia & $0-6 \mathrm{~m}$ & $1200-2070$ & Chisholm (2000) \\
\hline Hydrolithon onkodes & Ishigaki Is (Ryukyu Is) & upper fore reef & 2044 & Matsuda (1989) \\
\hline Hydrolithon onkodes & Lizard Island, Australia & $0-3 \mathrm{~m}$ & $820-3310$ & Chisholm (2000) \\
\hline Porolithon onkodes & Penguin Bank, Hawaii & $40-100 \mathrm{~m}$ & 2100 & Agegian et al. (1988) \\
\hline Neogoniolithon fosliei & Lizard Island, Australia & $0-6 \mathrm{~m}$ & $1542-2815$ & Chisholm (1988) \\
\hline Porolithon onkodes & Lizard Island, Australia & $0-6 \mathrm{~m}$ & 947-3599 & Chisholm (1988) \\
\hline Porolithon & Barbados & fringing reef & 2378 & Stearn et al. (1977) \\
\hline Coralline pavement & One Tree Island, Australia & $0-1 \mathrm{~m}$ & 4000 & Kinsey (1985) \\
\hline Corallina elongata & Marseille, France & $0.5-1 \mathrm{~m}$ & 5037 & El Haïkali et al. (2004) \\
\hline Porolithon onkodes & Rangiroa, Polynesia & reef flat & 7400 & Payri (2000) \\
\hline Free-living algae & & & 187 & This study $(n=14)$ \\
\hline mainly Lithothamnion spp. & Pontian Islands shelf, west Meditte. & $70-100 \mathrm{~m}$ & 8 & Bracchi and Basso (2012) \\
\hline mainly Lithothamnion spp. & Pontian Islands shelf, west Meditte. & $40-70 \mathrm{~m}$ & 32 & Bracchi and Basso (2012) \\
\hline Lithothamnion coralliodes & Cilento shelf, west Mediterranean & $47 \mathrm{~m}$ & 91 & Savini et al. (2012) \\
\hline Rhodolith bed & Arvoredo Island, southern Brazil & $7-20 \mathrm{~m}$ & $55-136$ & Gherardi (2004) \\
\hline Lithothamnion corallioides & Mannin Bay, Ireland & $0-10 \mathrm{~m}$ & 29-64 & Bosence and Wilson (2003) \\
\hline Lithothamnion corallioides & Galway, Ireland & $<10 \mathrm{~m}$ & $88-164$ & Bosence (1980) \\
\hline Phymatolithon calcareum & Mannin Bay, Ireland & $0-10 \mathrm{~m}$ & $79-249$ & Bosence and Wilson (2003) \\
\hline Phymalithon calcareum maerl & Mallorca-Menorca shelf, Mediterranean. & $40-85 \mathrm{~m}$ & 210 & Canals and Ballesteros (1997) \\
\hline Phymatolithon calcareum & Galway, Ireland & $<10 \mathrm{~m}$ & $79-422$ & Bosence (1980) \\
\hline Lithothamnion glaciale & Troms, Norway & $18 \mathrm{~m}$ & $420-630$ & Freiwald and Henrich (1994) \\
\hline Lithothamnion coralliodes & Bay of Brest, France & $0-10 \mathrm{~m}$ & 876 & Potin et al. (1990) \\
\hline Rhodolith bed & Abrolhos shelf, Brazil & $20-110 \mathrm{~m}$ & 1000 & Amado-Filho et al. (2012) \\
\hline Lithothamnion glaciale & Troms, Norway & $7 \mathrm{~m}$ & $895-1432$ & Freiwald and Henrich (1994) \\
\hline Lithothamnion coralliodes & Bay of Brest, France & $1-10 \mathrm{~m}$ & $145-3100$ & Martin et al. (2006) \\
\hline
\end{tabular}

Table 5. Accumulation rates of free-living coralline algae. Coralline algae in Bosence (1985) were predominantly Neogoniolithon species.

\begin{tabular}{llrl}
\hline Species & Location & $\begin{array}{r}\mathrm{CaCO}_{3} \text { accumulation } \\
\left(\mathrm{mm} \mathrm{kyr}^{-1}\right)\end{array}$ & Reference \\
\hline Rhodolith (maerl) & Troms district, Norway & 1400 & Freiwald (1998) \\
Mixed coralline algae & Troms district, Norway & 900 & Freiwald (1998) \\
Coralline algae & Orkney Islands, Scotland & 80 & Farrow et al. (1984) \\
Branched coralline algae & Tavernier Key, Florida, USA & 450 & Bosence (1985) \\
Rhodolith (maerl) & St Mawes Bank, Falmouth, UK & 500 & Bosence (1980) \\
\hline
\end{tabular}

living algae was $22 \mathrm{~g} \mathrm{C}$-inorganic $\mathrm{m}^{-2} \mathrm{yr}^{-1}$ and $150 \mathrm{~g} \mathrm{C}$ inorganic $\mathrm{m}^{-2} \mathrm{yr}^{-1}$ for CCA. Thus net inorganic production by coralline algae of $108 \mathrm{~g} \mathrm{C}$-inorganic $\mathrm{m}^{-2} \mathrm{yr}^{-1}$ and

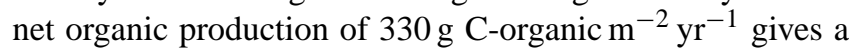
$\mathrm{PIC}$ : POC ratio of 0.33 (PIC is the particular inorganic car- bon and POC the particular organic carbon). The PIC: POC ratio for free-living algae was 0.13 and 0.40 for the CCA. Significantly, a similar PIC : POC range of ratios of 0.23-0.29 was also observed for coccolithophores (Engel et al., 2005). 


\subsection{Global carbon accumulation}

The long-term removal of $\mathrm{C}$ requires the fixed carbon to remain stored for 100-1000 years (Gattuso et al., 1998). The global long-term deposition rate of free-living coralline algae is $500 \mathrm{~mm} \mathrm{kyr}^{-1}$ (Table 5) and the accumulation rates range from 80 to $1400 \mathrm{~mm} \mathrm{kyr}^{-1}$ for temperate (Orkney Island, Scotland) to polar (Troms $\emptyset$ district, Norway) systems. The calcium carbonate production by free-living algae $\left(187 \mathrm{~g} \mathrm{CaCO}_{3} \mathrm{~m}^{-2} \mathrm{yr}^{-1}\right)$ with a calcite density of $2.71 \mathrm{~g} \mathrm{~cm}^{-3}$ (DeFoe and Compton, 1925) corresponds to a sediment accretion of $70 \mathrm{~mm} \mathrm{kyr}^{-1}$, while for CCA this corresponds to a sediment accretion of $450 \mathrm{~mm} \mathrm{kyr}^{-1}$. Given the accretion rate of $500 \mathrm{~mm} \mathrm{kyr}^{-1}$, the preservation potential of coralline algae would be $64 \%$. This is consistent with the empirically calculated calcium carbonate preservation of $60 \%$ (Milliman, 1993). However, if the preservation of CCA is excluded because of the lack of available accretion rates, and heavy grazing (Steneck, 1986), the preservation potential for this morphotype would be $14 \%$. As the complete preservation potential for coralline algae still requires further refining, the potential total carbon burial is estimated based on the sum of total organic production and the inorganic production. The estimated potential total burial for the free-living algae was $0.4 \times 10^{9}$ and $1.2 \times 10^{9} \mathrm{t} \mathrm{C} \mathrm{yr}^{-1}$ for CCA giving a potential total carbon burial of $1.6 \times 10^{9} \mathrm{t} \mathrm{C} \mathrm{yr}^{-1}$ for coralline algae.

\section{Future prospects: ocean acidification and rising temperature}

Increasing atmospheric $p \mathrm{CO}_{2}$ will increase $\mathrm{DIC}$ and shift the equilibrium of the carbonate system to higher $\mathrm{CO}_{2}$ and bicarbonate ion-levels, lower carbonate ion concentration and lower pH (Feely et al., 2009). Coralline algae may be vulnerable to the warming and lowering sea water $\mathrm{pH}$ of sea water, caused by recent increases in anthropogenic $\mathrm{CO}_{2}$ (Kleypas et al., 2006); the sensitivity of algae is of widespread importance and it has generated several recent reviews which find coralline algae may show mixed response to global change (Nelson et al., 2009; Koch et al., 2012; Brodie et al., 2014; McCoy and Kamenos, 2015). For example, high $p \mathrm{CO}_{2}$ conditions negatively affect community growth (Jokiel et al., 2008; Hofmann et al., 2012; Ragazzola et al., 2012), recruitment (Kuffner et al., 2008), calcification (Anthony et al., 2008; Gao and Zheng, 2010), size and abundance (Kuffner et al., 2008; Hall-Spencer et al., 2008; Porzio et al., 2011; Kroeker et al., 2013; McCoy and Ragazzola, 2014; Donnarumma et al., 2014), as well as epithelial integrity (Burdett et al., 2012). Conversely, increased atmospheric $p \mathrm{CO}_{2}$ is expected to have a positive impact on the organic production and growth of algae due to increased $p \mathrm{CO}_{2}$ availability (Hendriks et al., 2010). For example, Semesi et al. (2009) observed an increase in photosynthetic rates of coralline algae with a rising $p \mathrm{CO}_{2}$ of seawater, however, whether this also translates to their accretion at longer timescales is still not clear.

The HMC cell-walls of coralline algae, containing 7.7$28.8 \% \mathrm{MgCO}_{3}$, play a crucial role in their response to the increased temperature and acidification of seawater (Basso, 2012; Kamenos et al., 2013). Biogenic HMC cell-walls, containing $>8-12 \% \mathrm{MgCO}_{3}$, have a high solubility and are sensitive to ocean acidification (Andersson et al., 2008). Despite this, there is evidence that they can continue to calcify in elevated $p \mathrm{CO}_{2}$ (Kamenos et al., 2013; Martin et al., 2013b; Diaz-Pulido et al., 2014) but with altered skeletal integrity (Ragazzola et al., 2012; Kamenos et al., 2013; McCoy and Ragazzola, 2014). Overall it is expected that any decreasing abundance and growth of coralline algae may have knock-on consequences for worldwide coastal ecosystems (Johansen, 1981; Martin and Gattuso, 2009; Basso, 2012).

\section{Conclusions}

The ongoing increase of anthropogenic $\mathrm{CO}_{2}$ is causing warming and acidification of the world's oceans. Reduction of $\mathrm{CO}_{2}$ to a sustainable level is required to avoid further environmental damage. We calculate coralline algae to have a global average net primary production of $0.7 \times 10^{9} \mathrm{tC} \mathrm{yr}^{-1}$ and an estimated total global $\mathrm{CaCO}_{3}$ production of $1.8 \times 10^{9} \mathrm{tCaCO}_{3} \mathrm{yr}^{-1}$ which corresponds to a net inorganic production of $0.2 \times 10^{9} \mathrm{t}$ inorganic $\mathrm{C} \mathrm{yr}^{-1}$. With their substantial preservation potential and the longevity of the deposits they create, coralline algae have a significant capacity to store carbon. However, we are still uncertain of the impact future global change is likely to have on that capacity. Given their storage potential, empirical studies are now needed to refine these calculations.

\section{The Supplement related to this article is available online at doi:10.5194/bg-12-6429-2015-supplement.}

Acknowledgements. Nicolas A. Kamenos was in receipt of NERC (UK) grant (NE/H017305/1). This paper is a contribution to the UK Ocean Acidification Research Programme. This review profited greatly from discussions with Appy Sluijs and Jack Middelburg and their constructive feedback and criticism of the thesis. We are grateful to both of them.

Edited by: G. Herndl 


\section{References}

Adey, W. H. and Adey, P. J.: Studies on the biosystematics and ecology of the epilithic crustose Corallinaceae of the British Isles, Br. Phycol. J., 8, 343-407, doi:10.1080/00071617300650381, 1973.

Adey, W. H. and Macintyre, I. G.: Crustose coralline algae: A reevaluation in the Geological Sciences, Geol. Soc. Am. Bull., 84, 883-904, doi:10.1130/0016-7606(1973)84<883, 1973.

Adey, W. H. and McKibbin, D.: Studies on the maerl species Phymatolithon calcareum (Pallas) nov. comb. and Lithothamnium coralloides Crouan in the Ria de Vigo, Bot. Mar., 13, 100-106, 1970.

Adey, W. H. and Vassar, M. J.: Colonization, succession and growth rates of tropical crustose coralline algae (Rhodophyta, Cryptonemiales), Phycologia, 14, 55-69, 1975.

Agegian, C. R., Mackenzie, F. T., Tribble, J. S., and Sabine, C.: Carbonate production and flux from a mid-depth bank ecosystem, Penguin Bank, Hawaii, in: Biogeochemical cycling and fluxes between the deep euphotic zone and other oceanic realms, edited by: Agegian, C. R., 5-32, National Undersea Research Program, Rockville, Maryland, USA, 5-32, 1988.

Aguirre, J., Riding, R., and Braga, J. C.: Diversity of coralline red algae: origination and extinction patterns from the Early Cretaceous to the Pleistocene, Paleonotological Soc., 26, 651-667, 2000.

Amado-Filho, G. M., Moura, R. L., Bastos, A. C., Salgado, L. T., Sumida, P. Y., Guth, A. Z., Francini-Filho, R. B., PereiraFilho, G. H., Abrantes, D. P., Brasileiro, P. S., Bahia, R. G., Leal, R. N., Kaufman, L., Kleypas, J. A., Farina, M., and Thompson, F. L.: Rhodolith beds are major $\mathrm{CaCO}_{3}$ bio-factories in the tropical South West Atlantic, PLoS One, 7, 35171, doi:10.1371/journal.pone.0035171, 2012.

Andersson, A. J., Mackenzie, F. T., and Bates, N. R.: Life on the margin: implications of ocean acidification on $\mathrm{Mg}$-calcite, high latitude and cold-water marine calcifiers, Mar. Ecol.-Prog. Ser., 373, 265-273, doi:10.3354/meps07639, 2008.

Anthony, K. R. N., Kline, D. I., Diaz-Pulido, G., Dove, S., and Hoegh-Guldberg, O.: Ocean acidification causes bleaching and productivity loss in coral reef builders, P. Natl. Acad. Sci. USA, 105, 17442-17446, doi:10.1073/pnas.0804478105, 2008.

Atkinson, M. J. and Grigg, R. W.: Model of a coral reef ecosystem, II. Gross and net benthic primary production at French Frigate Shoals, Hawaii, Coral Reefs, 3, 13-22, 1984.

Barron, C., Duarte, C. M., Frankignoulle, M. and Borges, A. V: Organic carbon metabolism and carbonate dynamics in a Mediterranean Seagrass (Posidonia oceanica) meadow, Estuar. Coast, 29, 417-426, 2006.

Basso, D.: Deep rhodolith distribution in the Pontian Islands, Italy: a model for the paleoecology of a temperate sea, Palaeogeogr. Palaeoecol., 137, 173-187, doi:10.1016/S0031-0182(97)00099$0,1998$.

Basso, D.: Carbonate production by calcareous red algae and global change, Geodiversitas, 34, 13-33, 2012.

Beardall, J. and Raven, J. A.: The potential effects of global climate change on microalgal photosynthesis, growth and ecology, Phycologia, 43, 26-40, 2004.

Birkett, D. A., Maggs, C. A., and Dring, M. J.: Maerl (volume V). An overview of dynamic and sensitivity characteristics for conservation management of marine SACs, Scottisch Assoc. Mar. Sci., V, 1-117, 1998.
Borowitzka, M. A.: Mechanisms in algal calcification, in: Progress in Phycological Research, edited by: Round, F. E. and Chapman, D. J., Elsevier Biomedical Press, New York, Amsterdam, London, 1, 138-177, 1982.

Bosence, D. and Wilson, J.: Maerl growth, carbonate production rates and accumulation rates in the NE Atlantic, Aquat. Conserv. Mar. Freshw. Ecosyst., 13, S21-S31, doi:10.1002/aqc.565, 2003.

Bosence, D. W. J.: Sedimentary facies, production rates and facies models for recent coralline algal gravels, Geol. J., 15, 91-111, 1980.

Bosence, D. W. J.: The occurrence and ecology of recent Rhodoliths - A review, in: Coated grains, edited by: Peryt, T. M., SpringerVerlag, Berlin, 225-242, 1983.

Bosence, D. W. J.: The morphology and ecology of a moundbuilding coralline alga (Neogoniolithon strictum) from the Florida Keys, Palaeontology, 28, 189-206, 1985.

Bracchi, V. A. and Basso, D.: The contribution of calcareous algae to the biogenic carbonates of the continental shelf: Pontian Islands, Tyrrhenian Sea, Italy, Geodiversitas, 34, 61-76, 2012.

Brodie, J., Williamson, C. J., Smale, D. A., Kamenos, N. A., Mieszkowska, N., Santos, R., Cunliffe, M., Steinke, M., Yesson, C., Anderson, K. M., Asnaghi, V., Brownlee, C., Burdett, H. L., Burrows, M. T., Collins, S., Donohue, P. J. C., Harvey, B., Foggo, A., Noisette, F., Nunes, J., Ragazzola, F., Raven, J. A., Schmidt, D. N., Suggett, D., Teichberg, M., and Hall-Spencer, J. M.: The future of the northeast Atlantic benthic flora in a high $\mathrm{CO}_{2}$ world, Ecol. Evol., 4, 2787-2798, 2014.

Burdett, H. L., Aloisio, E., Calosi, P., Findlay, H. S., Widdicombe, S., Hatton, A., and Kamenos, N. A.: The effect of chronic and acute low $\mathrm{pH}$ on the intracellular DMSP production and epithelial cell morphology of red coralline algae, Mar. Biol. Res., 8, 756-763, 2012.

Burdett, H. L., Keddie, V., MacArthur, N., McDowall, L., McLeish, J., Spielvogel, E., Hatton, A. D., and Kamenos, N. A.: Dynamic photoinhibition exhibited by red coralline algae in the red sea, BMC Plant Biol., 14, 139, doi:10.1186/1471-2229-14-139, 2014.

Cabioch, J.: Morphogenesis and generic concepts in coralline algae - a reappraisal, Helgoländer Meeresuntersuchungen, 42, 493509, doi:10.1007/BF02365623, 1988.

Cadee, G. C. and Hegeman, J.: Primary production of the benthic microflora living on tidal flats in the Dutch Wadden Sea, Netherlands J. Sea Res., 8, 260-291, 1974.

Caldeira, K. and Wickett, M. E.: Ocean model predictions of chemistry changes from carbon dioxide emissions to the atmosphere and ocean, J. Geophys. Res., 110, 1-12, doi:10.1029/2004JC002671, 2005.

Canals, M. and Ballesteros, E.: Production of carbonate particles by phytobenthic communities on the Mallorca-Menorca shelf, northwestern Mediterranean Sea, Deep-Sea Res. Pt. II, 44, 611 629, doi:10.1016/S0967-0645(96)00095-1, 1997.

Charpy-Roubaud, C. and Sournia, A.: The comparative estimation of phytoplanktonic, microphytobenthic and macrophytobenthic primary production in the oceans, Mar. Microb. Food Webs, 4, 31-57, 1990.

Chisholm, J. R. M.: Photosynthesis, calcification, and photoadaptation, in reef-building crustose coralline algae on the Great Barrier Reef, PhD thesis, James Cook Univ., ResearchOnline@ JCU, 223 pp., 1988. 
Chisholm, J. R. M.: Calcification by crustose coralline algae on the northern Great Barrier Reef, Australia, Limnol. Oceanogr., 45, 1476-1484, doi:10.4319/lo.2000.45.7.1476, 2000.

Chisholm, J. R. M.: Primary productivity of reef-building crustose coralline algae, Limnol. Oceanogr., 48, 1376-1387, 2003.

Collins, M., Knutti, R., Arblaster, J., Dufresne, J.-L., Fichefet, T., Friedlingstein, P., Gao, X., Gutowski Jr, W. J., Johns, T., Krinner, G., Shongwe, M., Tebaldi, C., Weaver, A. J., and Wehner, M.: Long-term climate change: projections, commitments and irreversibility, in: Climate Change 2013: The Physical Basis. Contribution of Working Group I to the Fifth Assessment Report of the Intergovernmental Panel on Climate Change, edited by: Stocker, T. F., Qin, D., Plattner, G.-K., Tignor, M., Allen, S. K., Boschung, J., Nauels, A., Xia, Y., Bex, V., and Midgley, P. M., Cambridge University Press, Cambridge, United Kingdom and New York, NY, USA, 1031-1106, 2013.

Cubasch, U., Wuebbles, D., Chen, D., Facchini, M. C., Frame, D., Mahowald, N., and Winther, J.-G.: Introduction, in Climate Change 2013: The Physical Basis. Contribution of Working Group I to the Fifth Assessment Report of the Intergovernmental Panel on Climate Change, edited by: Stocker, T. F., Qin, D., Plattner, G.-K., Tignor, M., Allen, S. K., Boschung, J., Nauels, A., Xia, Y., Bex, V., and Midgley, P. M., Cambridge University Press, Cambridge, United Kingdom and New York, NY, USA, 121-155, 2013.

DeFoe, O. K. and Compton, A. H.: The density of rock salt and calcite, Phys. Rev., 25, 618-620, 1925.

Del Giorgio, P. A. and Duarte, C. M.: Respiration in the open ocean, Nature, 420, 379-384, doi:10.1038/nature01165, 2002.

Denman, K. L., Brasseur, G., Chidtaisong, A., Clais, P., Cox, P. M., Dickinson, R. E., Hauglustaine, D., Heinze, C., Holland, E., Jacob, D., Lohmann, U., Ramachandran, S., da Silva Dias, P. L., Wofsy, S. C., and Zhang, X.: Couplings between changes in the climate system and biogeochemistry, in Climate Change 2007: The Physical Science Basis, Contributing to Working Group I to the Fourth Assessment Report of the Intergovernmental Panel on Climate Change, edited by: Solomon, S., Qin, D., Manning M., Chen, Z., Marquis, M., Averyt, K. B., Tignor, M., and Miller, H. L., Cambridge University Press, Cambridge, United Kingdom and New York, NY, USA, 501-568, 2007.

Diaz-Pulido, G., Nash, M. C., Anthony, K. R. N., Bender, D., Opdyke, B. N., Reyes-Nivia, C., and Troitzsch, U.: Greenhouse conditions induce mineralogical changes and dolomite accumulation in coralline algae on tropical reefs, Nat. Commun., 5, 3310, 2014.

Diugokencky, E. and Tans, P.: NOAA/ESRL: available at: http: //www.esrl.noaa.gov/gmd/ccgg/trends/, last access: 14 October 2015.

Donnarumma, L., Lombardi, C., Cocito, S., and Gambi, M. C.: Settlement pattern of Posidonia oceanica epibionts along a gradient of ocean acidification: an approach with mimics, Mediterranean Marine Science, 15, 498-509, doi:10.12681/mms.677, 2014.

Duarte, C. M. and Cebrian, J.: The fate of marine autotrophic production, Limnol. Oceanogr., 41, 1758-1766, 1996.

Duarte, C. M., Middelburg, J. J., and Caraco, N.: Major role of marine vegetation on the oceanic carbon cycle, Biogeosciences, 2, 1-8, doi:10.5194/bg-2-1-2005, 2005.

Eakin, C. M.: Where have all the carbonates gone? A model comparison of calcium carbonate budgets before and after the 1982-
1983 El Nino at Uva Island in the eastern Pacific, Coral Reefs, 15, 109-119, 1996.

Edyvean, R. G. J. and Ford, H.: Growth rates of Lithophyllum incrustans (Corallinales, Rhodophyta) from South West Wales, Br. Phycol. J., 22, 139-146, 1987.

El Haïkali, B., Bensoussan, N., Romano, J.-C., and Bousquet, V.: Estimation of photosynthesis and calcification rates of Corallina elongata Ellis and Solander, 1786, by measurements of dissolved oxygen, pH and total alkalinity, Sci. Mar., 68, 45-56, 2004.

Engel, A., Zondervan, I., Aerts, K., Beaufort, L., Benthien, A., Chou, L., Delille, B., Gattuso, J.-P., Harlay, J., Heemann, C., Hoffmann, L., Nejstgaard, J., Pizay, M.-D., Rochelle-Newall, E., Schneider, U., Terbrueggen, A., and Riebesell, U.: Testing the direct effect of $\mathrm{CO}_{2}$ concentration on a bloom of the coccolithophorid Emiliania huxleyi in mesocosm experiments, Limnol. Oceanogr., 50, 493-507, 2005.

Farrow, G. E., Allen, N. H., and Ekpan, E. B.: Bioclastic carbonate sedimentation on a high-latitude, tide-dominated shelf: northeast Orkney Islands, Scotland, J. Sediment. Petrol., 54, 373-393, 1984.

Feely, R. A., Doney, S. C., and Cooley, S. R.: Ocean acidification: present conditions and future changes in a high- $\mathrm{CO}_{2}$ world, Oceanography, 22, 36-47, doi:10.5670/oceanog.2009.95, 2009.

Field, C. B., Behrenfeld, M. J., Randerson, J. T., and Falkowski, P.: Primary production of the biosphere: Integrating terrestrial and oceanic components, Science, 281, 237-240, doi:10.1126/science.281.5374.237, 1998.

Figueiredo, M. A. O., Horta, P. A., Pedrini, A. G., and Nunes, J. M. C.: Benthic marine algae of the coral reefs of Brazil: A literature review, Oecologia Bras., 12, 258-269, 2008.

Foster, M. S.: Rhodoliths: Between rocks and soft places, J. Phycol., 37, 659-667, 2001.

Frankignoulle, M.: A complete set of buffer factors for acid/base $\mathrm{CO}_{2}$ system in seawater, J. Mar. Syst., 5, 111-118, 1994.

Freiwald, A.: Modern nearshore cold-temperate calcaeous sediments in the Troms districts, northern Norway, J. Sediment. Res., 68, 763-776, 1998.

Freiwald, A. and Henrich, R.: Reefal corallina algal build-ups within the Arctic Circle: morphology and sedimentary dynamics under extreme environmental seasonality, Sedimentology, 41, 963-984, 1994.

Gao, K. S. and Zheng, Y. Q.: Combined effects of ocean acidification and solar UV radiation on photosynthesis, growth, pigmentation and calcification of the coralline alga Corallina sessilis (Rhodophyta), Glob. Change Biol., 16, 2388-2398, 2010.

Gattuso, J.-P., Frankignoulle, M., and Wollast, R.: Carbon and carbonate deposits, Annu. Rev. Ecol. Syst., 29, 405-434, 1998.

Gattuso, J.-P., Gentili, B., Duarte, C. M., Kleypas, J. A., Middelburg, J. J., and Antoine, D.: Light availability in the coastal ocean: impact on the distribution of benthic photosynthetic organisms and their contribution to primary production, Biogeosciences, 3, 489-513, doi:10.5194/bg-3-489-2006, 2006.

Gherardi, D. F. M.: Community structure and carbonate production of a temperate Rhodolith Bank from Arvoredo Island, Southern Brazil, Brazilian J. Oceanogr, 52, 207-224, 2004.

Gieskes, W. W. C. and Kraay, G. W.: The phytoplankton spring bloom in Dutch coastal waters of the North Sea, Netherlands J. Sea Res., 9, 166-196, 1975. 
Goreau, T. F.: Calcium carbonate deposition by coralline algae and corals in relation to their roles as reef-builders, Ann. N. Y. Acad. Sci., 109, 127-168, 1963.

Hall-Spencer, J. M. and Moore, P. G.: Scallop dredging has profound, long-term impacts on maerl habitats, ICES J. Mar. Sci., 57, 1407-1415, doi:10.1006/jmsc.2000.0918, 2000.

Hall-Spencer, J. M., Rodolfo-Metalpa, R., Martin, S., Ransome, E., Fine, M., Turner, S. M., Rowley, S. J., Tedesco, D., and Buia, M.-C.: Volcanic carbon dioxide vents show ecosystem effects of ocean acidification, Nature, 454, 96-99, doi:10.1038/nature07051, 2008.

Hendriks, I. E., Duarte, C. M., and Álvarez, M.: Vulnerability of marine biodiversity to ocean acidification: A meta-analysis, Estuar. Coast. Shelf Sci., 86, 157-164, doi:10.1016/j.ecss.2009.11.022, 2010.

Hofmann, L. C., Yildiz, G., Hanelt, D., and Bischof, K.: Physiological responses of the calcifying rhodophyte, Corallina officinalis (L.), to future $\mathrm{CO}_{2}$ levels, Mar. Biol., 159, 783-792, 2012.

Johansen, H. W.: Coralline Algae, A first synthesis, Boca Raton, Florida, CRC Press, 1-239, 1981.

Jokiel, P. L., Rodgers, K. S., Kuffner, I. B., Andersson, A. J., Cox, E. F., and Mackenzie, F. T.: Ocean acidification and calcifying reef organisms: a mesocosm investigation, Coral Reef., 27, 473-483, doi:10.1007/s00338-008-0380-9, 2008.

Kamenos, N. A.: North Atlantic summers have warmed more than winters since 1353, and the response of marine zooplankton, $\mathrm{P}$. Natl. Acad. Sci. USA, 107, 1-6, doi:10.1073/pnas.1006141107, 2010.

Kamenos, N. A. and Law, A.: Temperature controls on coralline algal skeletal growth, J. Phycol., 46, 331-335, doi:10.1111/j.15298817.2009.00780.x, 2010.

Kamenos, N. A. and Moore, P. G.: Substratum heterogeneity of dredged vs un-dredged maerl grounds, J. Mar. Biol. Assoc. UK, 83, 411-413, doi:10.1017/S0025315403007264h, 2003.

Kamenos, N. A., Moore, P. G., and Hall-Spencer, J. M.: Maerl grounds provide both refuge and high growth potential for juvenile queen scallops (Aequipecten opercularis L.), J. Exp. Mar. Biol. Ecol., 313, 241-254, doi:10.1016/j.jembe.2004.08.007, 2004.

Kamenos, N. A., Cusack, M., and Moore, P. G.: Coralline algae are global palaeothermometers with bi-weekly resolution, Geochim. Cosmochim. Ac., 72, 771-779, 2008.

Kamenos, N. A., Burdett, H. L., Aloisio, E., Findlay, H. S., Martin, S., Longbone, C., Dunn, J., Widdicombe, S., and Calosi, P.: Coralline algal structure is more sensitive to rate, rather than the magnitude, of ocean acidification, Glob. Change Biol., 19, 36213628, doi:10.1111/gcb.12351, 2013.

Kinsey, D. W.: Metabolism, calcification and carbon production I: System level studies, Proc. 5th Int. Coral Reef Symp., Tahiti, 27 May-1 June 5, 505-526, 1985.

Kirby, C. J. and Gosselink, J. G.: Primary production in a Louisana Gulf Coast Spartina alterniflora marsh, Ecology, 57, 1052-1059, 1976.

Kirtman, B., Power, S. B., Adedoyin, A. J., Boer, G. J., Bojariu, R., Camilloni, I., Doblas-Reyes, F., Fiore, A. M., Kimoto, M., Meehl, G., Prather, M., Sarr, A., Schar, C., Sutton, R., van Oldenburgh, G. J., Vecchi, G., and Wang, H.-J.: Near-term climate change: projections and predictability, in: Climate Change 2013: The Physical Basis. Contribution of Working Group I to the Fifth
Assessment Report of the Intergovernmental Panel on Climate Change, edited by: Stocker, T. F., Qin, D., Plattner, G.-K., Tignor, M., Allen, S. K., Boschung, J., Nauels, A., Xia, Y., Bex, V., and Midgley, P. M., Cambridge University Press, Cambridge, United Kingdom and New York, NY, USA, 955-1008, 2013.

Kleypas, J. A., Feely, R. A. A., Fabry, V. J., Langdon, C., Sabine, C. L., and Robbins, L. L.: Impacts of ocean acidification on coral reefs and other marine calcifiers: A guide for future research, in: Workshop report, St. Petersburg, Florida, USA, 18-20, 2006.

Koch, M., Bowes, G., Ross, C., and Zhang, X.-H.: Climate change and ocean acidification effects on seagrasses and marine macroalgae, Glob. Change Biol., 19, 103-132, 2012.

Kroeker, K. J., Kordas, R. L., Crim, R., Hendriks, I. E., Ramajo, L., Singh, G. S., Duarte, C. M., and Gattuso, J.-P.: Impacts of ocean acidification on marine organisms: quantifying sensitivities and interaction with warming, Glob. Change Biol., 19, 1884-1896, 2013.

Kuffner, I. B., Andersson, A. J., Jokiel, P. L., Rodgers, K. S., and Mackenzie, F. T.: Decreased abundance of crustose coralline algae due to ocean acidification, Nat. Geosci., 1, 114-117, doi:10.1038/ngeo100, 2008.

Larkum, A. W. D.: The primary productivity of plant communities on coral reefs, in: Perspectives on coral reefs, edited by: Barnes, D. J., Australian Institute of Marine Science, Townsville, 221230, 1983.

Littler, M. M.: The productivity of Hawaiian fringing-reef crustose Corallinaceae and an experimental evaluation of production methodology, Limnol. Oceanogr., 18, 946-952, 1973.

Littler, M. M. and Doty, M. S.: Ecological components structuring the seaward edges of tropical Pacific reefs: the distribution, communities and productivity of Porolithon, J. Ecol., 63, 117-129, 1975.

Littler, M. M. and Murray, S. N.: The primary productivity of marine macrophytes from a rocky intertidal community, Mar. Biol., 27, 131-135, 1974.

Littler, M. M., Littler, D. S., Blair, S. M., and Norris, J. N.: Deepwater plant communities from an uncharted seamount off San Salvador Island, Bahamas: distribution, abundance, and primary productivity, Deep-Sea Res., 33, 881-892, 1986.

Littler, M. M., Littler, D. S., and Dennis Hanisak, M.: Deep-water rhodolith distribution, productivity, and growth history at sites of formation and subsequent degradation, J. Exp. Mar. Biol. Ecol., 150, 163-182, doi:10.1016/0022-0981(91)90066-6, 1991.

Marsh, J. A.: Primary productivity of reef-building calcareous Red Algae, Ecology, 51, 255-263, 1970.

Martin, S. and Gattuso, J.-P.: Response of Mediterranean coralline algae to ocean acidification and elevated temperature, Glob. Chang. Biol., 15, 2089-2100, doi:10.1111/j.13652486.2009.01874.x, 2009.

Martin, S., Clavier, J., Guarini, J.-M., Chauvaud, L., Hily, C., Grall, J., Thouzeau, G., Jean, F., and Richard, J.: Comparison of Zostera marina and maerl community metabolism, Aquat. Bot., 83, 161174, doi:10.1016/j.aquabot.2005.06.002, 2005.

Martin, S., Castets, M.-D., and Clavier, J.: Primary production, respiration and calcification of the temperate free-living coralline alga Lithothamnion corallioides, Aquat. Bot., 85, 121-128, doi:10.1016/j.aquabot.2006.02.005, 2006.

Martin, S., Clavier, J., Chauvaud, L., and Thouzeau, G.: Community metabolism in temperate maerl beds, I. Car- 
bon and carbonate fluxes, Mar. Ecol.-Prog. Ser., 335, 19-29, doi:10.3354/meps335019, 2007.

Martin, S., Charnoz, A., and Gattuso, J.-P.: Photosynthesis, respiration and calcification in the Mediterranean crustose coralline alga Lithophyllum cabiochae (Corallinales, Rhodophyta), Eur. J. Phycol., 48, 163-172, doi:10.1080/09670262.2013.786790, 2013a.

Martin, S., Cohu, S., Vignot, C., Zimmerman, G., and Gattuso, J. P.: One-year experiment on the physiological response of the Mediterranean crustose coralline alga, Lithophyllum cabiochae, to elevated $\mathrm{pCO}_{2}$ and temperature, Ecol. Evol., 3, 676-693, $2013 b$.

Matsuda, S.: Succesion and growth rates of encrusting crustose coralline algae (Rhodophyta, Cryptonemiales) in the upper forereef environment off Ishigaki Island, Ryukyu Islands, Coral Reefs, 7, 185-195, 1989.

McCoy, S. J. and Kamenos, N. A.: Coralline algae (Rhodophyta) in a changing world: Integrating ecological, physiological, and geochemical responses to global change, J. Phycol., 51, 6-24, 2015.

McCoy, S. J. and Ragazzola, F.: Skeletal trade-offs in coralline algae in response to ocean acidification, Nature Climate Change, 4, 719-723, 2014.

Meehl, G. A., Stocker, T. F., Collins, W. D., Friedlingstein, P., Gaye, A. T., Gregory, J. M., Kitoh, A., Knutti, R., Murphy, J. M., Noda, A., Raper, S. C. B., Watterson, I. G., Weaver, A. J., and Zhao, Z.-C.: Global climate projections, in: Climate Change 2007: The Physical Science Basis, Contributing to Working Group I to the Fourth Assessment Report of the Intergovernmental Panel on Climate Change, edited by: Solomon, S., Qin, D., Manning, M., Chen, Z., Marquis, M., Averyt, K. B., Tignor, M., and Miller, H. L., Cambridge University Press, Cambridge, United Kingdom and New York, NY, USA, 749-832, 2007.

Menard, H. W. and Smith, S. M.: Hypsometry of ocean basin provinces, J. Geophys. Res., 71, 4305-4325, 1966.

Milliman, J. D.: Production and accumulation of calcium carbonate in the ocean: budget of a nonsteady state, Global Biogeochem. Cy., 7, 927-957, 1993.

Moberly Jr., R.: Composition of magnesian calcites of algae and pelecypos by electron microprobe analysis, Sedimentology, 11, 61-82, 1968.

Nellemann, C., Corcoran, E., Duarte, C. M., Valdes, L., De Young, C., Fonseca, L., and Grimsditch, G.: Blue carbon, The role of oceans as carbon sinks, in: Blue carbon, The role of healthy oceans in binding carbon: A rapid response assessment, United Nations Environment Programme, GRID-Arendal, Arendal, Norway, 1-80, 2009.

Nelson, C. S.: An introductory perspective on non-tropical shelf carbonates, Sediment. Geol., 60, 3-12, 1988.

Nelson, W. A.: Calcified macroalgae - critical to coastal ecosystems and vulnerable to change: a review, Mar. Freshw. Res., 60, 787801,2009

Nienhuis, P. H. and Bree, B. H. H.: Production and ecology of eelgrass (Zostera marina L.) in the Grevelingen estuary, The Netherlands, before and after the closure, Hydrobiologia, 52, 5566, 1977.

Odum, E. P.: Energetics and ecosystems, in: Ecology of Halophytes, edited by: Reimold, R. J. and Queen, W. H., Academic Press, London, New York, San Francisco, 599-602, 1974.
Payri, C. E.: Production primaire et calcification des algues benthiques en milieu corallien, Oceanis, 26, 427-463, 2000.

Porzio, L., Buia, M. C., and Hall-Spencer, J. M.: Effects of ocean acidification on macroalgal communities, J. Exp. Mar. Biol. Ecol., 400, 278-287, doi:10.1016/j.jembe.2011.02.011, 2011.

Potin, P., Floc, J. Y., Augris, C., and Cabioch, J.: Annual growth rate of the calcareous red alga Lithothamnion corallioides (Corallinales, Rhodophyta) in the Bay of Brest, France, Hydrobiologia, 204/205, 263-267, 1990.

Ragazzola, F., Foster, L. C., Form, A., Anderson, P. S. L., Hansteen, T. H., and Fietzke, J.: Ocean acidification weakens the structural integrity of coralline algae, Glob. Change Biol., 18, 2804-2812, 2012.

Ranwell, S. D.: World resources of Spartina townsendii (Sensu lato) and economic use of Spartina marshland, J. Appl. Ecol., 4, 239256, 1966.

Roberts, R. D., Kühl, M., and Glud, R. N.: Primary production of crustose coralline red algae in a high Arctic fjord, J. Phycol., 38, 273-283, 2002.

Sabine, C. L., Feely, R. A., Gruber, N., Key, R. M., Lee, K., Bullister, J. L., Wanninkhof, R., Wong, C. S., Wallace, D. W. R., Tilbrooke, B., Millero, F. J., Peng, T., Kozyr, A., Ono, T., and Rios, A. F.: The oceanic sink for anthropogenic $\mathrm{CO}_{2}$, Science, 305, 367-371, 2004.

Savini, A., Basso, D., Bracchi, V. A., Corselli, C., and Penneta, M.: Maerl-bed mapping and carbonate quantification on submerged terraces offshore the Cilento peninsula (Tyrrhenian Sea, Italy), Geodiversitas, 34, 77-98, 2012.

Semesi, I. S., Kangwe, J., and Björk, M.: Alterations in seawater $\mathrm{pH}$ and $\mathrm{CO}_{2}$ affect calcification and photosynthesis in the tropical coralline alga, Hydrolithon sp. (Rhodophyta), Estuar. Coast. Shelf Sci., 84, 337-341, doi:10.1016/j.ecss.2009.03.038, 2009.

Sheveiko, S. V.: Life forms of coralline algae as an environmental indicator on reefs, in: Proc. 4th Int. Cor. Reef. Symp., Manila, 18-22 May, edited by: Gomez, E. D., Birkeland, C. E., Buddemeier, R. W., Johannes, R. E., Marsh, J. A., and Tsuda, R. Y., Marine Science Centre, Univ. Phillipines, Quezon City, Vol. 2, 461 pp., 1981.

Smith, J. E., Smith, C. M., and Hunter, C. L.: An experimental analysis of the effects of herbivory and nutrient enrichment on benthic community dynamics on a Hawaiian reef, Coral Reefs, 19, 332-342, doi:10.1007/s003380000124, 2001.

Smith, S. V.: Marine macrophytes as a global carbon sink, Science, 211, 838-840, doi:10.1126/science.211.4484.838, 1981.

Sournia, A.: Oxygen metabolism of a fringing reef in French polynesia, Helgoländer Wissenschaftliche Meeresuntersuchungen, 28, 401-410, doi:10.1007/BF01610589, 1976.

Stearn, C. W., Scoffin, T. P., and Martindale, W.: Calcium carbonate budget of a fringing reef on the west coast of Barbados. I: Zonation and productivity, B. Mar. Sci., 27, 479-510, 1977.

Steneck, R. S.: The ecology of coralline algal crusts: convergent patterns and adaptative strategies, Annu. Rev. Ecol. Syst., 17, 273 303, 1986.

Steneck, R. S. and Adey, W. H.: The role of environment in control of morphology in Lithophyllum congestum, a Caribbean algal ridge builder, Bot. Mar., 19, 197-215, 1976.

Thayer, G. W. and Adams, S. M.: Structural and functional aspects of a recently established Zostera marina community, in: Estuarine Research, Vol. 1: Chemistry, Biology and the Estuarine Sys- 
tem, edited by: Cronin, L. E., Academic Press, London, New York, San Francisco, 518-540, 1975.

Turner, R. E.: Geographic variations in salt marsh macrophyte production: a review, Contr. Mar. Sci., 20, 47-68, 1976.

Vooren, C. M.: Photosynthetic rates of benthic algae from the deep coral reef of Curacao, Aquat. Bot., 10, 143-159, 1981.

Walker, D. I. and Woelkerling, W. J.: Quantitative study of sediment contribution by epiphytic coralline red algae in seagrass meadows in Shark Bay, western Australia, Mar. Ecol.-Prog. Ser., 43, 71-77, 1988.

Wanders, J. B. W.: The role of benthic algae in the shallow reef of Curacao (Netherlands Antilles), I: primary productivity in the coral reef, Aquat. Bot., 2, 235-270, 1976.

Whittaker, R. H. and Likens, G. E.: Primary production: The biosphere and man, Hum. Ecol., 1, 357-369, doi:10.1007/BF01536732, 1973.
Wilson, S.: Environmental tolerances of free-living coralline algae (maerl): implications for European marine conservation, Biol. Conserv., 120, 279-289, doi:10.1016/j.biocon.2004.03.001, 2004.

Woodwell, G. M., Rich, P. H., and Hall, C. A.: Carbon in estuaries, in: Carbon and the Biosphere, edited by: Woodwell, G. M. and Pecan, E. V., AEC Symposium Series 30, NTIS U.S. Dept. of Commerce, Springfield, Virginia, 221-239, 1973.

Zar, J. H.: Measures of central tendency, in: Biostatistical analysis, edited by: Ryu, T., Prentence Hall, New Jersey, 20-31, 1999.

Zieman, J. C.: Quantitative and dynamic aspects of the ecology of turtle grass, Thalassia testudinum, in: Estuarine Research, Vol. 1: Chemistry, Biology and the Estuarine System, edited by: Cronin, L. E., Academic Press, London, New York, San Francisco, 541$562,1975$. 